\title{
ANALISIS POTENSI TSUNAMI DI LOMBOK UTARA
}

\section{POTENTIAL TSUNAMI ANALYSIS IN NORTH LOMBOK}

\author{
Eva Susan Ratuluhain ${ }^{1 *}$, I Wayan Nurjaya ${ }^{2}$, \& Nyoman M. N. Natih ${ }^{2}$ \\ ${ }^{1}$ Program Studi Ilmu Kelautan, Sekolah Pascasarjana, IPB University, Bogor, 16680, Indonesia \\ ${ }^{2}$ Departemen Ilmu Teknologi dan Kelautan, Fakultas Perikanan dan Ilmu Kelautan, \\ IPB University, Bogor, 16680, Indonesia \\ *E-mail: evasusanratuluhain@gmail.com
}

\begin{abstract}
The Flores Fault is the one of caused an earthquake on August 5, 2018 in Lombok Island. It is reported that this earthquake with magnitude of $7.0 \mathrm{Mw}$ caused a small tsunami with amplitude of $13.5 \mathrm{~cm}$ in the coastal area of Carik village, North Lombok. This study aimed to simulate a potential tsunami hazard from the Flores faults activity using the COMCOT v1.7 tsunami model which estimates potential tsunami height, tsunami arrival time, and potential tsunami affected areas. Historical earthquake data as an epicenter in the simulation was the earthquake on September 2, 2018, with the earthquake magnitude of 7 Mw. On the basis of the earthquake above, the model parameters was chosen, such as the depth of epicenter of $14 \mathrm{~km}$, width fault area of $47.9 \times 15.9 \mathrm{~km}$, dislocation of $2.5 \mathrm{~m}$, strike of $284^{\circ}$, slip of $64^{\circ}$, and dip of $88^{\circ}$. Simulation layer is divided into 3 layers based on nesting grid system with $464 \mathrm{~m}, 232 \mathrm{~m}$ and $77 \mathrm{~m}$ resolution, respectively. Bathymetric data were obtained from GEBCO with a 15-arc second grid size. Tsunami propagation simulation has been performed for duration of 30 minutes, which produced an initial tsunami height of $0.9 \mathrm{~m}$. The maximum tsunami height revealed from the simulation was between 1-2.5 $\mathrm{m}$ on land. Estimated arrival time of the tsunami in North Lombok was ftom 3 to 13 minutes. Simulation result showed that sub-district area of Bayan, Kayangan, Tanjung, and Gangga are affected potentially areas by the tsunami. The maximum height and arrival time of the tsunami in North Lombok have the potential to be destructive and can cause casualties, so that mitigation efforts are needed, such as socialization and training in dealing with tsunami hazards, planting coastal vegetation that is suitable for the substrate on the coast, and building offshore breakwaters.
\end{abstract}

Keywords: COMCOT v1.7, earthquake, Flores fault, North Lombok, tsunami

\begin{abstract}
ABSTRAK
Sesar Flores merupakan pemicu gempa bumi pada tanggal 5 Agustus 2018 di Pulau Lombok. Dilaporkan bahwa gempa bumi dengan kekuatan 7,0 $\mathrm{Mw}$ saat itu, telah menyebabkan tsunami kecil dengan ketinggian 13,5 cm di pesisir pantai Desa Carik, Lombok Utara. Studi ini bertujuan untuk mensimulasikan potensi bahaya tsunami yang berasal dari aktivitas sesar Flores menggunakan pemodelan tsunami COMCOT v1.7 untuk mengestimasi potensi tinggi tsunami, waktu tiba tsunami, dan potensi area terdampak tsunami. Data historis untuk pusat gempa bumi dalam simulasi adalah gempa bumi pada tanggal 2 September 2018, dengan asumsi kekuatan gempa 7,0 Mw. Berdasarkan data gempa bumi diatas, parameter yang dipilih berupa kedalaman sumber gempa $14 \mathrm{~km}$, luas patahan $47,9 \times 15,9 \mathrm{~km}$, dislokasi $2,5 \mathrm{~m}$, dan parameter strike $284^{\circ}$, dip $64^{\circ}$, dan slip $88^{\circ}$. Layer simulasi dibagi menjadi 3 berdasarkan sistem model bersarang, dengan reolusi masing-masing $464 \mathrm{~m}, 232 \mathrm{~m}$, dan $77 \mathrm{~m}$. Data batimetri diperoleh dari GEBCO dengan resolusi 15arcsecond. Waktu simulasi penjalaran tsunami yang dilakukan selama 30 menit, menghasilkan tinggi tsunami awal sebesar $0,9 \mathrm{~m}$. Tinggi tsunami maksimum yang teramati di darat adalah 1-2,5 $\mathrm{m}$. Estimasi waktu tiba gelombang pada pesisir Lombok Utara, adalah 3 sampai 13 menit. Hasil pemodelan menunjukkan bahwa wilayah Kecamatan Bayan, Kayangan, Tanjung, dan Gangga berpotensi terkena dampak tsunami. Tinggi maksimum dan kecepatan waktu tiba tsunami di Lombok Utara sangat berpotensi merusak dan dapat menimbulkan korban jiwa, sehingga perlu upaya mitigasi seperti sosialisasi dan pelatihan dalam menghadapi bahaya tsunami, penanaman vegetasi pantai yang sesuai dengan substrat di pantai, dan membangun pemecah gelombang lepas pantai.
\end{abstract}

Kata Kunci: COMCOT v1.7, gempa bumi, Lombok Utara, sesar Flores, tsunami 


\section{PENDAHULUAN}

Tsunami dikategorikan sebagai gelombang laut raksasa yang umumnya dibangkitkan dari peristiwa gempa bumi tektonik. Gempa bumi tektonik merupakan gempa yang terjadi pada batas pertemuan lempeng-lempeng tektonik. Indonesia terletak pada batas pertemuan 3 lempeng utama di dunia, yaitu Lempeng IndoAustralia, Lempeng Eurasia, dan Lempeng Pasifik. Hal ini mengakibatkan sejumlah pulau-pulau memiliki intensitas kegempaan yang cukup tinggi. Pulau Lombok diapit oleh 2 kawasan tektonik aktif yaitu bagian selatan di jalur pertemuan Lempeng Indo-Australia dengan Lempeng Eurasia, dan bagian utara di sekitar patahan aktif sesar Flores. Jalur sesar Flores merupakan tempat terjadinya gempa dangkal dengan kedalaman pusat gempa $<33$ km (Wang et al., 2020).

Sesar Flores terbentuk akibat desakan balik Lempeng Eurasia terhadap Lempeng Indo-Australia, sesar ini terbentang dari utara Flores hingga utara Bali dan terbagi atas beberapa segmen diantaranya segmen Sumbawa - Lombok dengan panjang sekitar $450 \mathrm{~km}$. Laju pergeseran sesar Flores sebesar 5,6-6,0 mm per tahun dengan kekuatan gempa dapat mencapai 8,0 Mw. (Koulali et al., 2016; Susilo et al., 2018). Jenis pergerakan sesar ini adalah sesar naik atau thrust fault yang dapat memicu tsunami (Sugianto et al., 2017; Supendi et al., 2020; Wang et al., 2020), seperti kejadian tsunami Flores pada tanggal 12 Desember 1992. McCaffrey \& Nabelek (1984) mengatakan bahwa aktivitas sesar ini telah diketahui sekitar 200 tahun yang lalu melalui kejadian gempa bumi di utara Flores.

Badan Meteorologi, Klimatologi dan Geofisika (BMKG) melaporkan bahwa gempa bumi Lombok Utara pada tanggal 5 Agustus 2018 berkekuatan 7,0 Mw dengan pusat gempa di darat, telah menyebabkan tsunami kecil dengan ketinggian $13 \mathrm{~cm}$ atau kurang dari 0,5 m di pantai Desa Carik. Rentetan kejadian gempa bumi masih berlangsung hingga bulan September 2018, yang didominasi dengan gempa dangkal serta beberapa diantaranya disertai dengan peringatan dini tsunami, seperti gempa bumi 2 September 2018 dengan pusat gempa di laut. Dampak gempa bumi Lombok Utara mengakibatkan 560 orang meninggal, lebih dari 140 ribu rumah penduduk rusak, retakan tanah dan likuifaksi di sejumlah desa yang tersebar di 5 kecamatan. Gempa besar yang terjadi akan memicu adanya gempa-gempa susulan sebagai bentuk penyelesaian pelepasan energi agar kembali stabil (Informasi Kebencanaan Bulanan Teraktual, BNPB 2019).

Kegempaan di Lombok Utara yang didominasi gempa dangkal, telah berlangsung sejak puluhan tahun yang lalu hingga saat ini, yaitu gempa bumi 20 Oktober 1979 (M5.9), 30 Mei 1979 (6.0), 17 Desember 1979 (M5.6), 20 Januari 2004 (M6.2), 22 Juni 2013 (M5.2), dan 29 Juli 2018 (M6.4), 5 Agustus 2018 (M7.0), dan 19 Agustus 2018 (M6.9) (Sasmi et al., 2020; Supendi et al., 2020). Gempa bumi tahun 2018 memiliki posisi pusat gempa yang berbeda dengan tahun-tahun sebelumnya, namun memberikan dampak yang signifikan terhadap Lombok Utara. Catatan sejarah kegempaan ini memberikan pemahaman baru bahwa gempa bumi memiliki siklus yang berulang. Asrurifak et al. (2010) mengatakan parameter gempa bumi dapat diteliti untuk menganalisis periode pengulangannya. Kelipatan 50 tahun untuk pengulangan gempa besar $(\geq 6,5)$ dan gempa kecil dengan pengulangannya hampir terjadi setiap hari. Sampai dengan saat ini belum ada teknologi yang mampu mendeteksi secara tepat waktu, lokasi, dan berapa besar kekuatan gempa bumi yang akan terjadi. Berdasarkan hal-hal tersebut maka perlu adanya kajian tentang bahaya tsunami untuk kemungkinan kasus terburuk yang dapat terjadi di Lombok Utara. Penelitian ini bertujuan menganalisis potensi tinggi tsunami, estimasi waktu tiba tsunami di darat, dan potensi wilayah terdampak tsunami di Lombok Utara. Pemodelan 
tsunami akan dilakukan dengan bantuan perangkat lunak COMCOT v1.7, yang merupakan program open source untuk mensimulasikan penjalaran tsunami dari sumber pembangkitan tsunami sampai ke area pantai. Hasil output COMCOT berupa tinggi dan waktu tiba tsunami akan digunakan selanjutnya untuk memprediksi wilayah terdampak bencana tsunami di Lombok Utara.

\section{METODE PENELITIAN}

\subsection{Wilayah Kajian}

Lokasi yang dikaji sebagai daerah model tsunami adalah Lombok Utara pada posisi $7.494^{\circ}-8.544^{\circ} \mathrm{LS}$ dan $115.877^{\circ}-$ $117.069^{\circ}$ BT (kotak merah). Lokasi kajian disajikan pada Gambar 1 .

\subsection{Sumber Data}

Dalam menyusun skenario gempa bumi pembangkit tsunami, diperlukan data historis gempa bumi, data parameter sesar, dan data batimetri. Data historis gempa bumi yang dipilih dari BMKG adalah gempa bumi pada tanggal 2 September 2018, yang merupakan gempa bumi disertai dengan peringatan dini tsunami. Skenario tsunami menggunakan gempa bumi berkekuatan 7,0 Mw. Pemilihan gempa bumi ini disesuaikan dengan syarat gempa bumi yang berpotensi membangkitkan tsunami diantaranya pusat gempa (epicenter) berada di laut, sumber kedalaman gempa $<30 \mathrm{~km}$ (gempa dangkal), dan sumber gempa berasal dari sesar aktif dengan tipe sesar naik/turun. Data parameter sesar diperoleh dari katalog USGS (The United States Geological Survey) (USGS, 2019) (Tabel 1).

Data batimetri diperoleh dari (The General Bathymetric Chart of The Ocean) GEBCO dengan resolusi grid 15-arc second (464 m). Luas wilayah kajian (Figure 1) akan dibagi berdasarkan nesting grid system menjadi 4 bagian, yaitu layer01 (layer domain), layer02, layer03a dan layer03b sebagai sub-layer. Pembagian layer simulasi dilakukan agar penjalaran tsunami dapat terlihat dengan jelas di wilayah pesisir Lombok Utara. Daerah fokus pengamatan pada Layer03a mencakup wilayah pesisir Kecamatan Bayan dan Kecamatan Kayangan, sedangkan layer03b mencakup pesisir

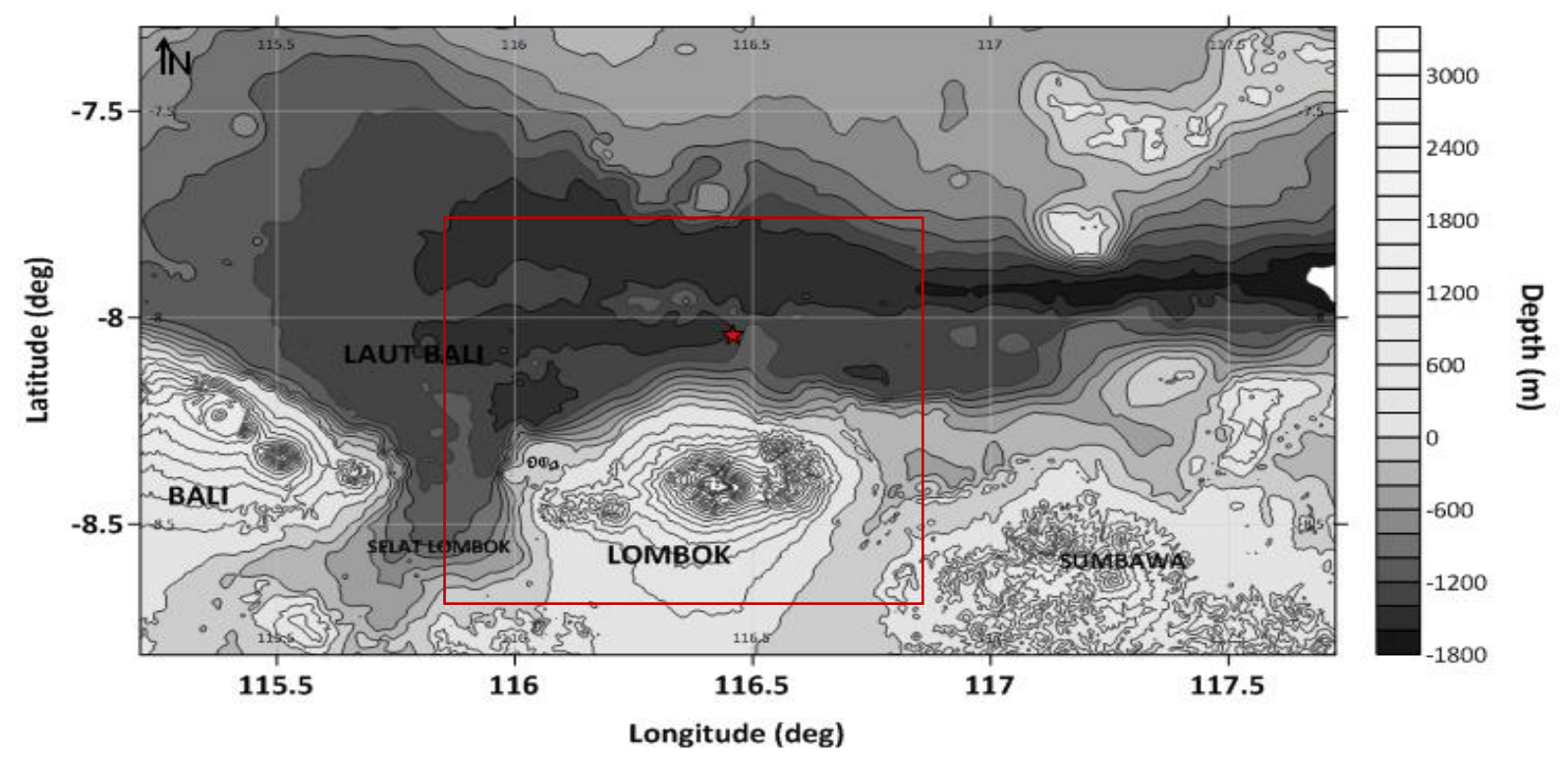

Gambar 1. Lokasi penelitian di Lombok Utara (simbol bintang merah merupakan episentrum).

Figure 1. Research site in North Lombok (red star symbol is an epicenter). 
Tabel 1. Parameter patahan untuk simulasi tsunami skenario gempa 7,0 Mw (USGS, 2019).

Table 1. Fault parameters for tsunami simulation of $7.0 \mathrm{Mw}$ earthquake scenario (USGS, 2019).

\begin{tabular}{lcc}
\hline \multicolumn{1}{c}{ Parameter } & Dimension & Unit \\
\hline Length (Panjang) & 47.863 & $\mathrm{~km}$ \\
Width (Lebar) & 15.849 & $\mathrm{~km}$ \\
Epicenter (Pusat gempa bumi) & 14 & $\mathrm{~km}$ \\
Dislocation (pergeseran lempeng) & 2.5 & $\mathrm{~m}$ \\
Strike (sudut strike) & 284 & degree \\
Dip (sudut dip) & 64 & degree \\
Slip (sudut slip/rake) & 88 & degree \\
\hline
\end{tabular}

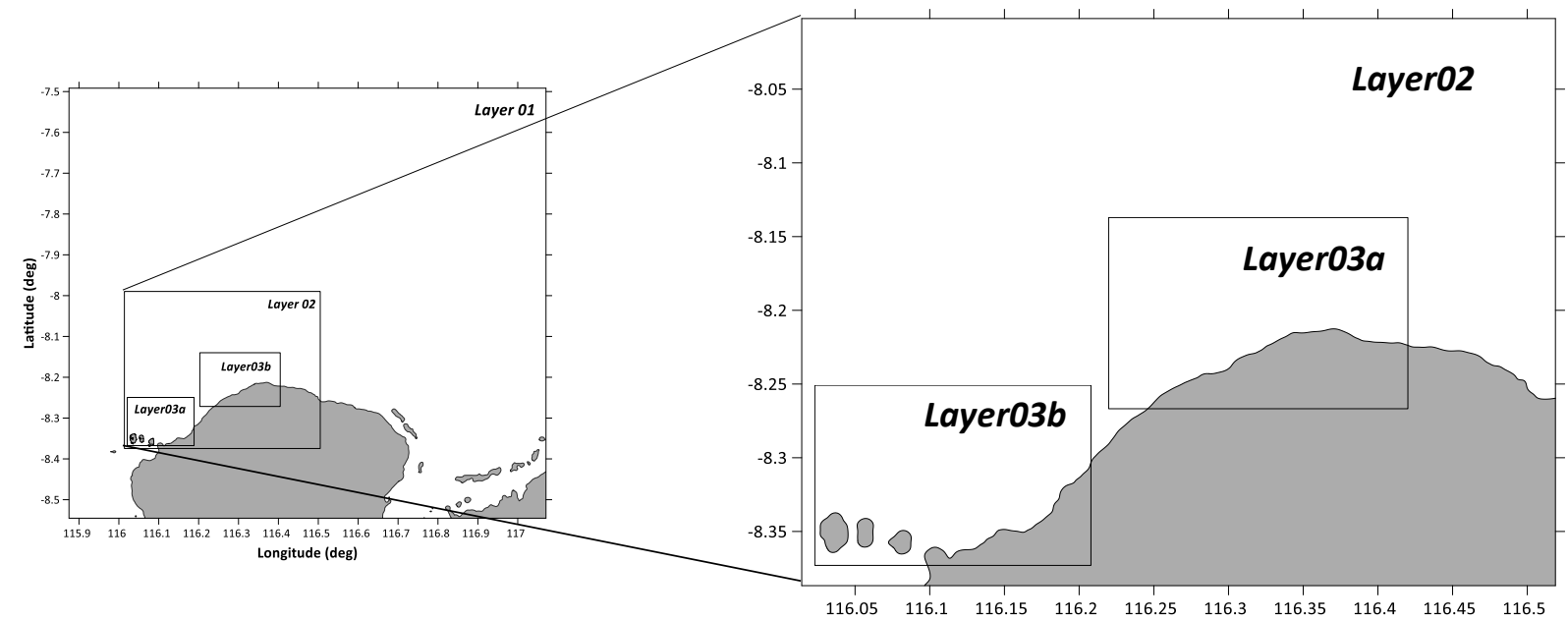

Gambar 2. Pembagian layer simulasi dalam model perambatan tsunami berdasarkan sistem grid bersarang.

Figure 2. The division of simulation layers in the tsunami propagation model based on a nested grid system.

Kecamatan Gangga, Kecamatan Tanjung, dan Kecamatan Pemenang. Resolusi spasial pada layer02 dan layer03 adalah $155 \mathrm{~m}$ dan $77 \mathrm{~m}$.

\subsection{Pemodelan Tsunami dengan COMCOT dan Konfigurasi Model} Simulasi model tsunami di Lombok Utara dilakukan dengan bantuan program open source COMCOT (Cornell Multi-grid Coupled Model) v1.7, yang dibangun oleh Prof. L $-\mathrm{F}$ Liu dari Cornell University. Perangkat lunak COMCOT telah banyak digunakan untuk mensimulasikan beberapa kejadian tsunami seperti tsunami Sumba tahun 1977 (Pradjoko et al., 2014), tsunami
Iquique, Chile 2014 (An et al., 2014), tsunami Mentawai tahun 2010 (Hill et al., 2012; Mutmainah et al., 2016), dan tsunami Samudra Hindia tahun 2004 (Wang \& Philip, 2006; Rasyif et al., 2019).

COMCOT merupakan program open source yang mengaplikasikan persamaan gelombang panjang atau persamaan air dangkal dalam mensimulasikan penjalaran tsunami dari sumber pembangkitan tsunami sampai ke area pantai. COMCOT mengusung skema beda hingga leap-frog untuk menyelesaikan persamaan air dangkal dalam sistem grid bersarang. Data input yang diperlukan untuk simulasi penjalaran tsunami berupa koordinat sumber atau episenter, 
kedalaman titik gempa, serta parameter gempa (Table 1). Output model berupa tinggi tsunami pada setiap detik akan digunakan kemudian untuk menganalisis waktu penjalaran tsunami ke setiap titik pengamatan sepanjang area terdampak di pantai. Konfigurasi model dibangun menggunakan persamaan nonlinier dalam koordinat cartesian, dengan melibatkan faktor gesekan dasar untuk menggambarkan gerakan aliran saat memasuki perairan dangkal (An et al., 2014). Persamaan nonlinier dalam koordinat cartesian dan persamaan gesekan dasar dapat ditulis sebagai berikut (Wang, 2009):

$$
\begin{aligned}
& \frac{\partial \eta}{\partial t}+\left\{\frac{\partial P}{\partial x}+\frac{\partial Q}{\partial y}\right\}=-\frac{\partial h}{\partial t} \ldots \ldots \ldots \ldots \ldots \ldots \ldots \ldots \ldots . . . \cdots \\
& \frac{\partial p}{\partial t}+\frac{\partial}{\partial x}\left\{\frac{p^{\mathbb{2}}}{H}\right\}+\frac{\partial}{\partial y}\left\{\frac{P Q}{H}\right\}+g H \frac{\partial \eta}{\partial x}+F_{x}=0
\end{aligned}
$$

$\frac{\partial Q}{\partial t}+\frac{\partial}{\partial x}\left\{\frac{P Q}{H}\right\}+\frac{\partial}{\partial y}\left\{\frac{Q^{2}}{H}\right\}+g H \frac{\partial \eta}{\partial y}+F_{y}=0$

$F_{x}=\frac{g n^{2}}{H^{7 / a}} P\left(P^{2}+Q^{2}\right)^{1 / 2}$

$F_{y}=\frac{g n^{2}}{H^{7 / a}} Q\left(P^{2}+Q^{2}\right)^{1 / 2}$

Keterangan: $H=$ total kedalaman air $(\mathrm{m}), P$ dan $Q=$ volume fluks dalam arah $\mathrm{x}$ dan $\mathrm{y}$ $\left(\mathrm{m}^{2} / \mathrm{s}\right), g=$ percepatan gravitasi $\left(\mathrm{m} / \mathrm{s}^{2}\right), F_{x}$ dan $F_{y}=$ gesekan dasar arah $\mathrm{x}$ dan y, dan $n=$ koefisien gesekan dasar.

Persamaan gesekan dasar yang dimodelkan menggunakan formula Manning (Manning's formula). Koefisien gesekan dasar (n) dalam COMCOT digunakan untuk merepresentasikan karakteristik permukaan profil batimetri dan topografi wilayah kajian. Prasetya et al. (2011) mengatakan bahwa koefisien yang dipilih dapat berupa nilai tunggal untuk mewakili seluruh area pada wilayah kajian ataupun bervariasi sesuai dengan karakteristik batimetri dan topografi. Dalam penelitian ini, Manning's roughness coefficient yang dipilih untuk simulasi ini adalah nilai tunggal 0,013 (Li et al., 2012). Parameter panjang dan lebar patahan dalam hubungannya dengan pergerakan bidang patahan dihitung dengan menggunakan persamaan oleh Well's \& Cooppersmith (1994), sebagai berikut:

$\log L=(-3.5+0.74 * M w)$

$\log A=(-3.42+0.9 * M w)$

Keterangan: $L=$ panjang patahan $(\mathrm{km}), A=$ luas patahan $\left(\mathrm{km}^{2}\right), M w=$ besaran gempa.

\subsubsection{Analisis Data}

Skenario simulasi penjalaran tsunami dilakukan berdasarkan historis gempa bumi Lombok Utara berkekuatan 7,0 Mw. Skenario ini dijalankan dalam 4 layer simulasi dengan konfigurasi model pada layer pertama (domain) menggunakan persamaan linier, sedangkan layer berikutnya (sub-layer) menggunakan persamaan nonlinier dalam koordinat cartesian. Keempat layer simulasi model mencakup seluruh wilayah pesisir Lombok Utara. Durasi waktu simulasi penjalaran untuk kedua skenario adalah 30 menit. Hasil keluaran model (output) berupa tinggi tsunami dan waktu penjalaran, selanjutnya akan digunakan untuk memprediksi daerahdaerah pesisir dari 5 kecamatan yang rawan bencana tsunami di Lombok Utara.

\section{HASIL DAN PEMBAHASAN}

\subsection{Hasil}

\subsubsection{Deskripsi Wilayah Studi}

Lombok Utara merupakan kabupaten termuda di Provinsi Nusa Tenggara Barat yang berada pada bagian utara pulau Lombok dengan luas wilayah daratan $809,53 \mathrm{~km}^{2}$ dan luas wilayah perairan mencapai $594,71 \mathrm{~km}^{2}$ dengan panjang garis pantai $127 \mathrm{~km}^{2}$. Sebagian besar potensi alam di Lombok Utara dikembangkan untuk pariwisata. Wilayah Lombok Utara mencakup 3 pulau 
wisata terkenal, yang merupakan gugusan pulau-pulau kecil di Kabupaten Lombok Utara, Kecamatan Pemenang yaitu Gili Trawangan (terletak di ujung luar dari wilayah Lombok Utara), Gili Meno (terletak di bagian tengah) dan Gili Air. Gugusan pulau ini disebut juga sebagai Tiga Gili (BAPEDDA, 2011).

Profil batimetri Lombok Utara disajikan pada Gambar 4. Kecamatan Pemenang berjarak $\pm 40 \mathrm{~km}$ dari pusat gempa bumi, sedangkan jarak terdekat dengan pusat gempa bumi adalah Kecamatan Bayan. Perhitungan tingkat kemiringan dilakukan dengan membuat garis-garis transek dari episenter ke wilayah pesisir yang mewakili jarak terdekat dan terjauh dari pusat pembangkitan tsunami. Transek A mewakili jarak dari episenter ke Kecamatan Bayan, sedangkan Transek B dan C mewakili jarak dari episenter ke Gili Trawangan (Kecamatan Pemenang). Transek $\mathrm{C}$ menggambarkan karakteristik kemiringan lereng di Gili Trawangan jika ditarik garis tegak lurus arah utara sejajar dengan titik episenter. Transek A (Kecamatan Bayan) memiliki tingkat kemiringan lereng curam dengan gradien sebesar $16 \%$ dan panjang transek 15 $\mathrm{km}$, Transek B (Gili Trawangan) memiliki gradien sebesar $14,8 \%$ dengan panjang transek $42 \mathrm{~km}$, dan Transek C memiliki gradien lebih curam (24\%) dengan panjang transek $25 \mathrm{~km}$. Kedalaman perairan pada batas wilayah kajian (domain layer) mencapai $1800 \mathrm{~m}$, sedangkan kedalaman pada batas simulasi layer03b mencapai $1430 \mathrm{~m}$.

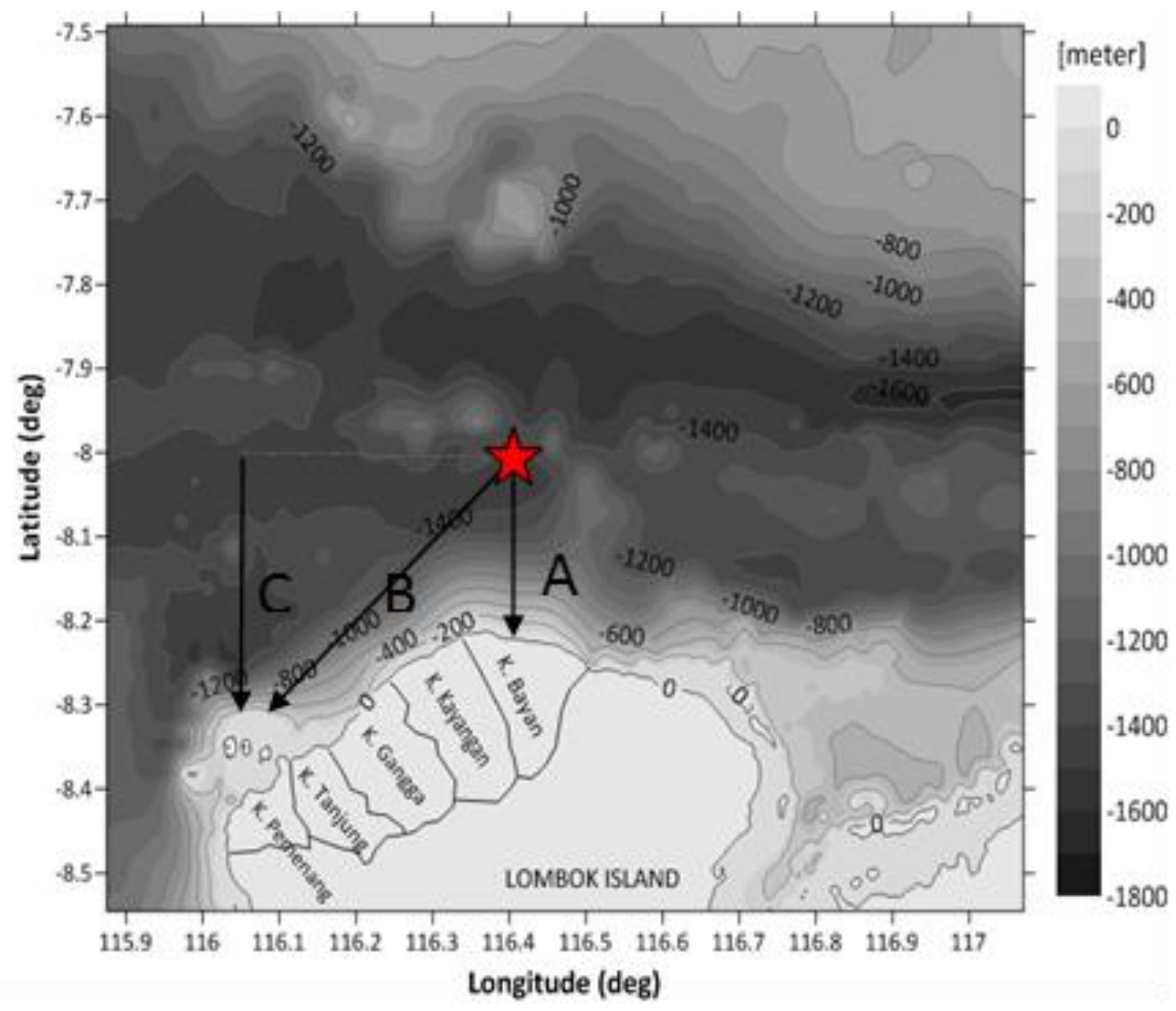

Gambar 4. Peta batimetri di lokasi penelitian. (A, B, C adalah garis transek untuk menggambarkan gradien dari episentrum ke 5 Kecamatan di Lombok Utara).

Figure 4. Bathymetry map on study site. (A, B, C is a transect line to describe a gradient from epicenter to 5 Sub-District at North Lombok). 


\subsubsection{Prediksi Tinggi Tsunami Waktu Tiba Tsunami, dan Potensi Wilayah Terdampak}

Hasil simulasi model penjalaran tsunami pada layer01, layer03a, dan layer03b untuk asumsi gempa bumi 7,0 Mw disajikan pada Gambar 5 dan 6. Episenter gempa bumi pembangkit tsunami berada pada kedalaman $1,377 \mathrm{~m}$ dengan posisi $8.130^{\circ} \mathrm{LS}$ dan $116.409^{\circ} \mathrm{BT}$. Pola gelombang bewarna merah dan biru mewakili elevasi muka air tinggi (pembentukan gelombang awal) dan elevasi muka air rendah (surut). Penurunan muka air laut atau surut mulai terlihat pada pesisir Kecamatan Bayan dan Kecamatan Kayangan, namun belum teramati sampai pada pesisir
Kecamatan Tanjung dan Kecamatan Pemenang. Pada menit ke-4, kondisi surut mulai terlihat pada pesisr Kecamatan Tanjung dan Gili Air (Gambar 5).

Tinggi gelombang awal pada saat pembangkitan adalah $0,9 \mathrm{~m}$. Pada ke-4 penjalaran, gelombang telah mencapai daerah-daerah di pesisir Kecamatan Bayan dan Kecamatan Kayangan (Gambar 5). Nilai run up teramati pada daerah kecamatan Bayan setinggi $\pm 2 \mathrm{~m}$. Pada menit ke-9 penjalaran, gelombang telah mencapai pesisir Kecamatan Gangga dan Kecamatan Tanjung dengan tinggi maksimum yang teramati $0,8-$ $1,7 \mathrm{~m}$. Penjalaran gelombang pada menit ke13 telah mencapai pesisir pulau Gili Mena
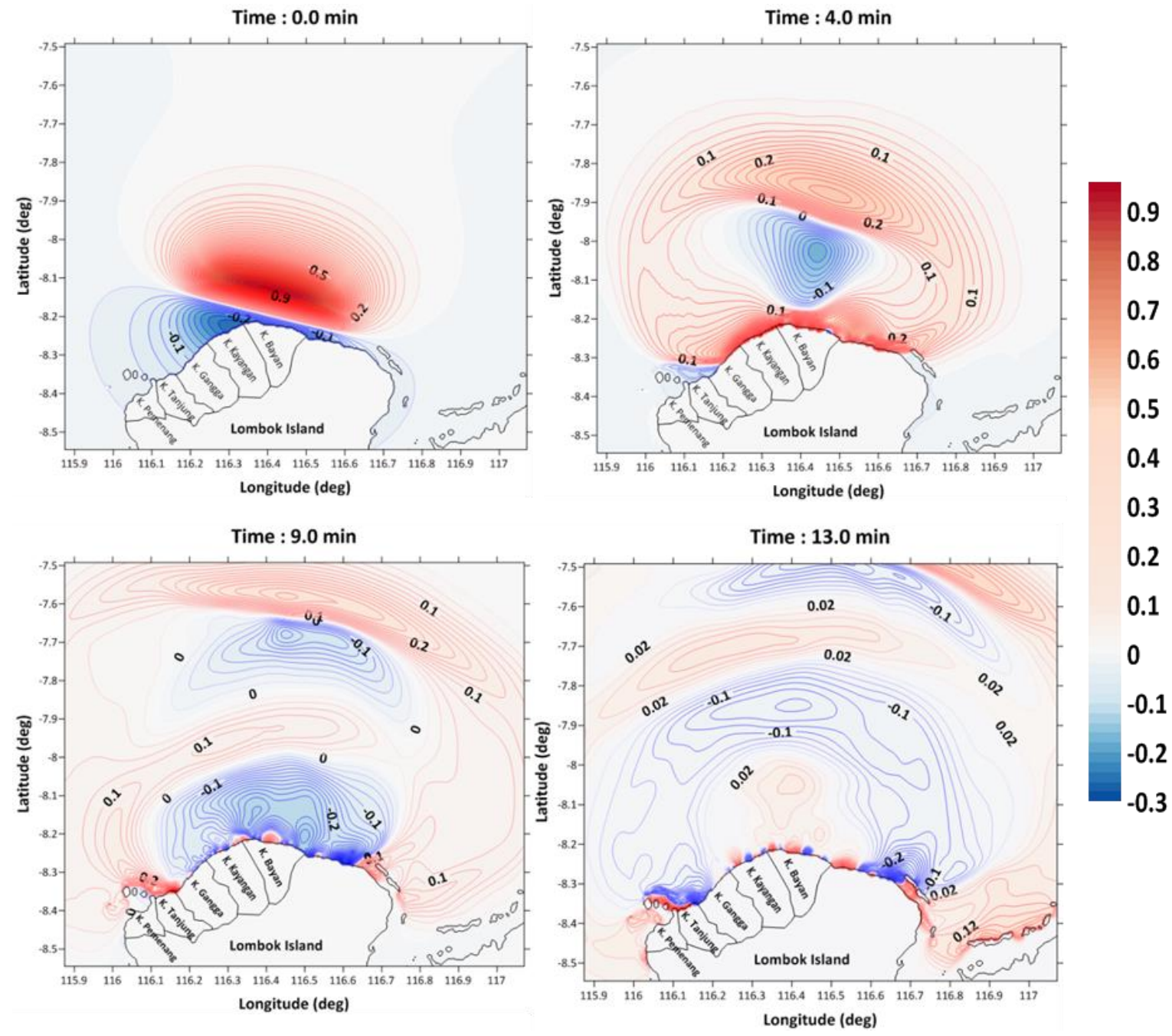

Gambar 5. Potret pola ketinggian tsunami pada layer01 pada menit ke 0, 4, 9, dan 13.

Figure 5. Snapshot of tsunami height pattern in layer01 at 0, 4, 9, and 13 minutes. 

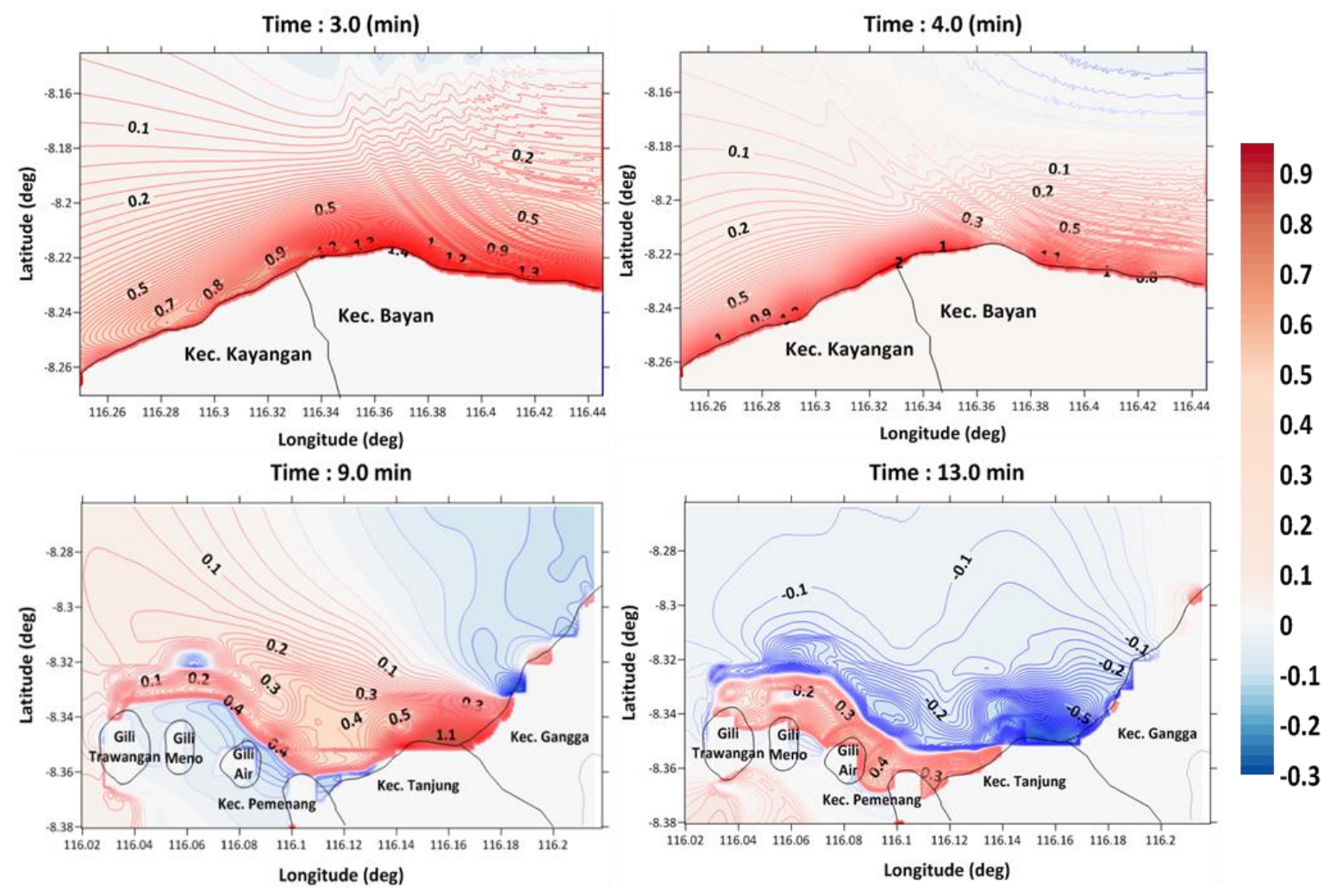

Gambar 6. Potret pola ketinggian tsunami pada layer03a pada menit ke-3 dan 4 (atas) dan layer03b pada menit ke-9 dan 13 (di bawah).

Figure 6. Snapshot of tsunami height pattern in layer03a at 3 and 4 minutes (above) and layer03b at 9 and 13 minutes (below).

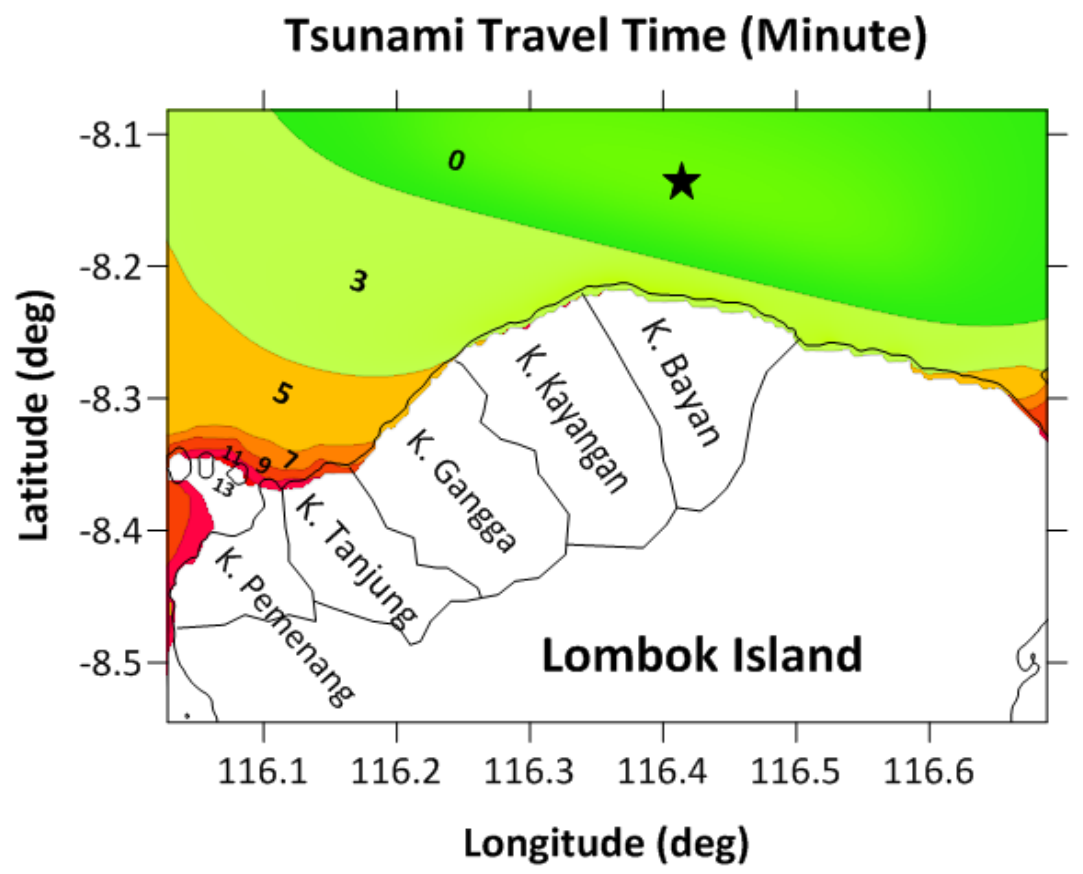

Gambar 7. Prediksi peta waktu perjalanan tsunami di Lombok Utara ( $\star$ : episentrum). Figure 7. Prediction of tsunami travel time maps at North Lombok ( $\star$ : epicenter). 
dan Gili Air dengan ketinggian 0,1-0,35 m (Gambar 6). Estimasi waktu tiba gelombang di sepanjang pesisir pantai Lombok Utara dicapai dalam rentang waktu 13 menit atau kurang dari 30 menit setelah terjadinya gempa bumi. Prediksi waktu tiba tsunami dapat dilihat pada Gambar 7. Pengeplotan waktu tiba tsunami dari pusat pembangkit tsunami (bintang hitam, Gambar 7) hingga Kecamatan Pemenang, diambil dari menit ke-0, 3, 5, 7, 9, 11, dan 13.

\subsection{Pembahasan}

Pola gelombang yang ditunjukkan pada Gambar 5, mengikuti arah strike yang diberikan $\left(284^{\circ}\right)$, dengan arah penjalaran menuju ke segala arah. Warna merah dan biru sebagai gambaran elevasi muka air naik dan turun, menunjukkan adanya deformasi pada bidang patahan yang bergerak naik saat terjadi gempa bumi pembangkit tsunami (Wang, 2009), sehingga kejadian tsunami sering ditandai dengan air surut (warna biru) di pantai sebagai precursor (tanda awal) dan diikuti dengan gelombang tinggi (Sugianto et al., 2017).

Kisaran tinggi gelombang awal saat terjadinya gempa bumi tektonik berkisar 1-2 $\mathrm{m}$ dan akan meningkat saat menjalar memasuki perairan yang lebih dangkal (IOC, 2006). Tinggi gelombang awal sangat dipengaruhi oleh besarnya kekuatan gempa, luas patahan serta dislokasi yang terjadi (Wang, 2009; Sugianto et al., 2017). Gelombang yang menjalar memasuki pantai akan mengalami deformasi (perubahan tinggi gelombang) akibat efek shoaling atau pendangkalan batimetri. Tinggi tsunami maksimum teramati pada Kecamatan Bayan, Kecamatan Kayangan, dan Kecamatan Tanjung (Gambar 5 dan 6), dengan kisaran 1,7-2,5 m. Profil batimetri yang landai dengan relief pantai yang rendah mengakibatkan tsunami akan semakin jauh mengimbas daratan (Helal \& Mehanna, 2008). Penjalaran tsunami pada menit ke-13 (Gambar 6) telah mencapai pesisir pulau Gili Air, Gili Meno, dan Gili Trawangan, dengan ketinggian yang semakin menurun yakni kurang dari $0,5 \mathrm{~m}$. Profil batimetri pada ketiga pulau wisata relatif curam, sehingga gelombang tidak signifikan mengimbas daratan. Dari ketiga pulau wisata, Gili Air akan mendapatkan dampak tsunami terlebih dahulu dibandingkan dengan Gili Meno dan Gili Trawangan, karena letaknya yang berdekatan dengan pulau induknya. Prajdoko et al. (2018) dalam tulisannya menjelaskan hal yang sama, dimana tsunami akan sampai pada area pantai yang lebih dekat dengan sumber pembangkitan tsunami. Kota Mataram yang terletak jauh dari episenter, dilanda tsunami dalam kurun waktu 10-20 menit, dengan ketinggian yang semakin berkurang. Hal ini juga disebabkan karena besaran gempa pembangkit tsunami hanya 6,4 Mw, sehingga ketinggian tsunami saat mencapai Kota Mataran kurang dari $1 \mathrm{~m}$.

Estimasi waktu tiba tercepat teramati di Kecamatan Bayan dan Kecamatan Kayangan dengan durasi waktu 3-4 menit (Gambar 5 dan 6). Hasil pemodelan menunjukkan bahwa jarak antara titik pengamatan dengan pusat gempa bumi tsunami sangat memengaruhi waktu tiba gelombang di pantai (Yudhicara et al., 2010; Ibad \& Santosa, 2014). Waktu tempuh penjalaran yang dicapai dalam kurun waktu kurang dari 40 menit, dikategorikan sebagai tsunami jarak dekat atau near field tsunami (IOC, 2006). Durasi waktu penjalaran selama 30 menit mempelihatkan hampir di sepanjang pesisir Lombok Utara mendapatkan dampak tsunami, dengan jarak jangkauan terjauh kurang dari $50 \mathrm{~km}$ dari pusat pembangkitan tsunami. Tsunami jarak dekat memberikan dampak destruktif pada pantai dalam radius $100 \mathrm{~km}$ (Diposaptono, 2006). Potensi wilayah terdampak tsunami di Lombok Utara disajikan pada Tabel 2

Tabel 2 memperlihatkan bahwa Kecamatan Pemenang khususnya Gili Trawangan, Gili Meno, dan Gili Air, mendapatkan pengaruh yang sangat rendah dibandingkan dengan 4 Kecamatan lainnya. Berdasarkan potensi tinggi tsunami dan 
estimasi waktu tiba tsunami dalam kaitannya dengan kondisi batimetri Lombok Utara, potensi wilayah terdampak tsunami yang signifikan adalah Kecamatan Bayan, Kecamatan Kayangan, Kecamatan Gangga, dan Kecamatan Tanjung (Tabel 2). Peta wilayah terdampak tsunami dapat dilihat pada Gambar 8.

Hal yang sama juga dipetakan oleh GIZ-IS (2013), yang memetakan daerah potensi rawan bencana tsunami di Pulau Lombok berdasarkan hasil simulasi model multi-skenario. Prediksi wilayah terdampak tsunami di Pulau Lombok yang dihasilkan khususnya di Lombok Utara adalah Labuan Carik (Kecamatan Bayan), Selengan (Kecamatan Kayangan), dan Sorong Jukung (Kecamatan Tanjung). Daerah antara Selengan dan Labuan Carik memperlihatkan arsiran merah yang cukup sedikit (tipis), sama dengan hasil penelitian ini pada menit ke-4 (Gambar 6). Daerah yang cukup terjal di lokasi ini merupakan daerah bertebing sehingga akan berakibat kurangnya imbas tsunami di darat. Daerah Sorong Jukung memperlihatkan arsiran warna merah yang cukup banyak (tebal), sama dengan hasil menit ke-9 Gambar 6. Bentuk cekungan pada daerah ini menyebabkan energi gelombang semakin besar ketika mencapai pantai dan dapat mengimbas daratan lebih jauh dibandingkan dengan pantai yang terjal. Peta prediksi bahaya tsunami di Lombok berdasarkan Mueck, 2013 dapat dilihat pada Gambar 9.

Secara topografis wilayah Kabupaten Lombok Utara merupakan daerah perbukitan atau pegunungan dimana kenampakan ini mulai terlihat pada bagian tengah dari utara ke selatan serta pemukiman penduduk yang berada relatif jauh dari garis pantai, sedangkan kawasan pesisir di sepanjang pantai merupakan kawasan minim penduduk dan umumnya hanya dihuni oleh nelayan tradisional. (Lugra \& Arifin, 2008; PKLU, 2016). Area terdampak tsunami di Lombok Utara (Gambar 8), merupakan kawasan dengan potensi wisata alam pantai yang menjadi tujuan destinasi wisatawan lokal maupun nasional, seperti Tiga Gili, Pantai Sire (Kab. Tanjung), Pantai Kerakas dan Pantai Lempenge (Kab. Gangga), dan Pantai Tanjung Menangis (Kab. Bayan). Tiga Gili merupakan kawasan wisata alam yang terletak di luar pulau induknya, sehingga perjalanan wisata membutuhkan akomodasi laut, sehingga banyak transportasi laut yang berlabuh di sepanjang pesisir pantai Tiga Gili. Pelabuhan Carik terletak di Kecamatan Bayan yang juga merupakan area terdampak

Tabel 2. Daerah yang berpotensi terkena tsunami di Lombok Utara.

Table 2. The potential affected areas by tsunami at North Lombok.

\begin{tabular}{|c|c|c|c|c|}
\hline \multirow{2}{*}{ Sub-district } & \multicolumn{2}{|c|}{$\begin{array}{c}\text { Tsunami scenario with } 7.0 \mathrm{Mw} \\
\text { assumtion of earthquake }\end{array}$} & \multirow{2}{*}{$\begin{array}{l}\text { Distance from } \\
\text { epicenter }(\mathrm{km})\end{array}$} & \multirow{2}{*}{$\begin{array}{l}\text { Coordinat of } \\
\text { tsunami height }\end{array}$} \\
\hline & $\begin{array}{l}\text { Tsunami travel } \\
\text { time }(\text { min })\end{array}$ & $\begin{array}{l}\text { Maximum } \\
\text { height }(m)\end{array}$ & & \\
\hline Bayan & $3-4$ & $2-2.5$ & \pm 5 & $\begin{array}{c}8^{\circ} 13^{\prime} 20^{\prime \prime} \mathrm{S} \\
116^{\circ} 40^{\prime} 44^{\prime \prime} \mathrm{E}\end{array}$ \\
\hline Kayangan & $5-6$ & 1.7 & \pm 13 & $\begin{array}{l}8^{\circ} 14^{\prime} 50^{\prime \prime} \mathrm{S} \\
116^{\circ} 37^{\prime} 2{ }^{\prime} \mathrm{E}\end{array}$ \\
\hline Gangga & $7-9$ & 1.5 & \pm 30 & 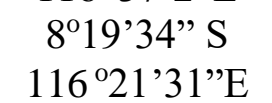 \\
\hline Tanjung & $10-11$ & $1.8-2$ & \pm 38 & $\begin{array}{l}8^{\circ} 20^{\prime} 46^{\prime \prime} \mathrm{S} \\
116^{\circ} 9^{\prime} 42^{\prime \prime} \mathrm{E}\end{array}$ \\
\hline Pemenang & 13 & $0.2-0.4$ & \pm 40 & $\begin{array}{c}8^{\circ} 20^{\prime} 37^{\prime \prime} \mathrm{S} \\
116^{\circ} 33^{\prime} 37.5^{\prime} \mathrm{E}\end{array}$ \\
\hline
\end{tabular}




\section{Affected potentially areas by the tsunami}

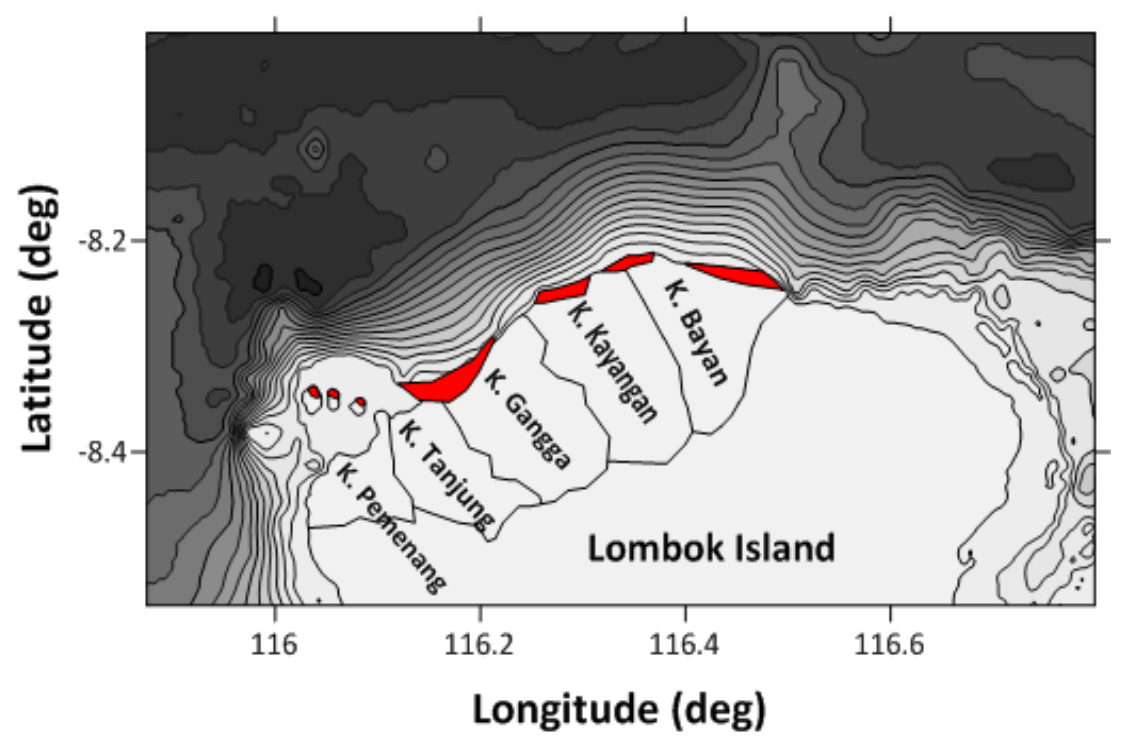

Gambar 8. Peta wilayah potensial terdampak di Lombok Utara (zona merah). Figure 8. Map of potensial affected areas at North Lombok (red zone).

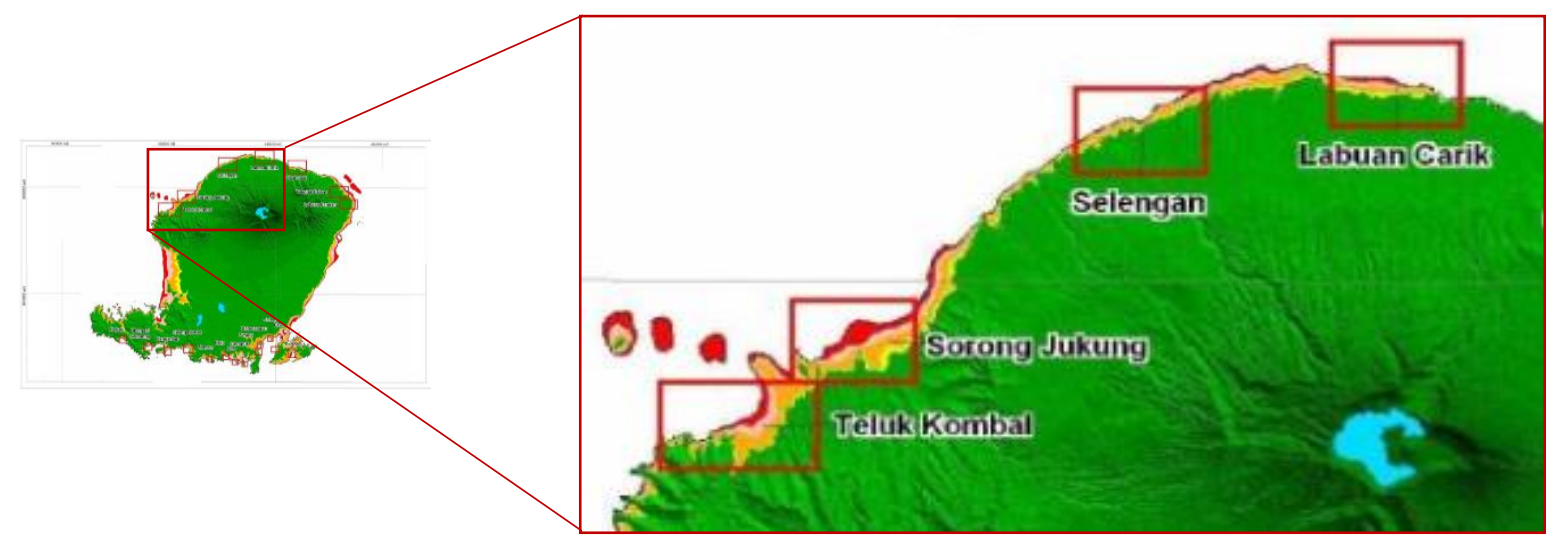

Gambar 9. Peta wilayah potensial terdampak di Pulau Lombok (GIZ-IS, 2013).

Figure 9. Map of potensial affected areas at Lombok Island (GIZ-IS, 2013).

tsunami dengan jarak yang paling dekat. Pengelolaan kawasan pesisir dengan kondisi pantai yang berhadapan langsung dengan laut lepas tanpa adanya struktur penghalang gelombang akan sangat berakibat fatal.

\section{KESIMPULAN}

Hasil simulasi penjalaran tsunami dengan skenario gempa bumi berkekuatan 7,0 Mw menghasilkan kisaran tinggi tsunami maksimum 1,5-2,5 m. Estimasi waktu tiba tsunami di sepanjang pesisir Lombok Utara adalah 3 sampai 13 menit dengan jarak tempuh terjauh pada radius $40 \mathrm{~km}$. Hasil simulasi menunjukkan bahwa sepanjang wilayah pesisir di 5 Kecamatan Lombok Utara berpotensi terdampak tsunami, dengan daerah yang signifikan adalah Kecamatan Bayan, Kayangan, Gangga dan Tanjung. Pemetaan daerah genangan akibat tsunami dapat dilakukan pada studi selanjutnya berdasarkan daerah terdampak tsunami di Lombok Utara. 


\section{UCAPAN TERIMA KASIH}

Penulis mengucapkan terima kasih kepada Bapak Eko Pradjoko, ST., M.Eng., Ph. D selaku dosen Fakultas Teknik Universitas Mataram, yang telah membantu dalam mempelajari model COMCOT v1.7, pihak GEBCO yang telah menyediakan data batimetri

(https://www.gebco.net/data_and_products/g ridded_bathymetry_data/), Prof. L-F Liu untuk program open source COMCOT, pihak USGS untuk penyediaan katalog dan parameter gempa bumi (https://earthquake.usgs.gov/earthquakes).

\section{DAFTAR PUSTAKA}

Asrurifak, M., M. Irsyam, B. Budiono, W. Triyoso, \& Hendriyawan. 2010. Development of spectral hazard map for Indonesia with a return period of 2500 years using probabilistic method. J. Civil Enginerring Dimension, 12(1): 52-56. https://doi.org/10.9744/ced.12.1.5262

Badan Perencanaan Pembangunan Daerah Kabupaten Lombok Utara (BAPPEDA). 2011. Peraturan Daerah Kabupaten Lombok Utara No. 9 Tahun 2011 tentang Rencana Tata Ruang Wilayah Kabupaten Lombok Utara Tahun 2011-2013. BAPPEDA Kabupaten Lombok Utara: Lombok Utara. $59 \mathrm{hlm}$.

Diposaptono, B.S. 2006. Tsunami. Buku Ilmiah Populer. Bandung. $300 \mathrm{hlm}$.

German International Cooporation International Services (GIZ-IS). 2013. Dokumen Teknis: Peta-Peta Bahaya Tsunami untuk Lombok. Jakarta. 24 hlm.

Helal, M.A. \& M.S. Mehanna. 2008. Tsunamis from nature to physics. Chaos, Solitons and Fractal, 36: 787796. https://doi.org/10.1016/j.chaos.2007.0 8.044

Hill, M.E., C.J. Borrero, Z. Huang, Q. Qiu, P. Banerjee, H.D. Natawidjaja, P. Elosegui, M.H. Fritz, W.B. Suwargadi, R.I. Pranantyo, L. Li, A.K. Macpherson, V. Skanavis, E.C. Synolakis, \& K. Sieh. 2012. The 2010 $\mathrm{M}_{\mathrm{w}} 7.8$ Mentawai earthquake: Very shallow source of a rare tsunami earthquake determind from tsunami field survey and near-field GPS data. J. Geophys. Res., 117: 1-21. https://doi.org/10.1029/2019JB00915 9

Ibad, M.I. \& B.J. Santosa. 2014. Pemodelan tsunami berdasarkan parameter mekanisme sumber gempa bumi dari analisis waveform tiga komponen gempa bumi Mentawai 25 Oktober 2010. J. Sains dan Seni Pomits, 3(2): 2337-3520.

https://doi.org/10.12962/j23373520.v $3 \mathrm{i} 2.6776$

Intergovernmental

Oceanographic Commission (IOC). 2006. Tsunami Glossary. Paris, UNESCO. IOC Technical Series. 44 p.

Koulali, A., S. Susilo, S. McClusky, I. Meilano, P. Cummins, P. Tregoning, G. Lister, J. Efendi, \& M.A. Syafi'i. 2016. Crustal strain partitioning and the associated earthquake hazard in the eastern Sunda-Banda Arc. Geophys. Res. Lett. 43: 1943-1949. https://doi.org/10.1002/2016GL06794 1

Lugra, I.W. \& L. Arifin. 2008. Potensi objek wisata pantai dan bahari di perairan utara Lombok ditinjau dari aspek geologi kelautan. J. Geo Kelautan., 6(2): 93-103. https://doi.org/10.32693/jgk.6.2.2008. 153

McCaffrey, R. \& J. Nabelek. 1984. The geometry of back arc thrusting along the Eastern Sunda Arc, Indonesia: Constraints from earthquake and 
gravity data. J. Geophys. Res. 89(B7): 6171-6179. https://doi.org/10.1029/jb089ib07p06 171

Mutmainah, H, D.W. Christiana, \& G. Kusumah. 2016. Tsunami Mentawai 25 Oktober 2010 (simulasi COMCOT v1.7) dan dampaknya kini terhadap pantai barat Mentawai. Jurnal Kelautan: Indonesia J. of Marine Science and Technology, 9(2): 175187. https://doi.org/10.21107/jk.v9i2.1917

Pemerintah Kabupaten Lombok Utara. 2016. Peraturan Pemerintah Daerah tentang Rencana Pembangunan Jangka Menengah Daerah Kabupaten Lombok Utara Tahun 2016-2021. Lombok (ID): PKLU.

Pradjoko, E., T. Kusuma, O. Setyandito, A. Suroso, \& B. Harianto. 2014. The tsunami run-up assement of 1977 Sumba earthquake in Kuta Center of Lombok, Indonesia. Prosedia Earth and Planetary Science, 14: 9-16. https//doi.org/10.1016/j.proeps.2015. 07.079

Prasetya, G., X. Wang, N. Palmer, \& G. Grant. 2011. Tsunami inundation modelling for riverton and new river estuary southland. GNS Science Consultancy Report. 87 p.

Pusat Studi Gempa Nasional (PUSGEN). 2017. Peta sumber dan bahaya gempa Indonesia Tahun 2017. Irsyam M., S. Widiyantoro, H.D. Natawidjaja, I. Meilano, A. Rudyantyo, S. Hidayati, W. Triyoso, R.N. Hanifa, D. Djarwadi, L. Faizal, dan Sunarjito, editor. Bandung. $361 \mathrm{hlm}$.

Pusat Studi Gempa Nasional (PUSGEN). 2018. Rangkaian gempa Lombok Provinsi Nusa Tenggara Barat, Indonesia 29 Juli 2018 (M6.4), 5 Agustus 2018 (M7.0), 19 Agustus 2018 (M6.9). Irsyam M., R.N. Hanifa, dan D. Djarwadi, editor. Bandung. $195 \mathrm{hlm}$.
Rasyif, T.M., K. Shigeru, Syamsidik, \& T. Okabe. 2019. Numerical simulation of morphological changes due to the 2004 tsunami wave around Banda Aceh, Indonesia. Geosciences, 9(125): 1-16. https://doi.org/10.3390/geosciences90 30125

Sasmi, A.T., A.D. Nugraha, Muzli, S. Widiyantoro, Zulfakriza, S. Wei, D.P. Sahara, A. Riyanto, N.T. Puspito, A. Priyono, T. Greenfield, H. Afif, P. Supendi, Daryono, Ardianto, D.K. Syahbana, Y.M. Husni, B.S. Prabowo, \& A.F.N. Sarjan. 2020. Hypocenter and magnitude analysis of aftershocks of the 2018 Lombok, Indonesia, earthquakes using local seismographic networks. Seismological Research Letter, 91(2A): 733-744.

https://doi.org/10.1785/0220190348

Sugianto, D., W.I. Nurjaya, N.M.N. Natih, \& W.W. Pandoe. 2017. Potensi rendaman tsunami di wilayah Lebak Banten. J. Kelautan Nasional, 12(1): 9-18.

https://doi.org/10.15578/jkn.v12i1.62 41

Supendi, P., A.D. Nugraha, S. Widiyantoro, J.D. Pesicek, C.H. Thurber, C.I. Abdullah, D. Daryono, S.H. Wiyono, H.A. Shiddiqi, \& S. Rosalia. 2020. Relocated aftershocks and background seismicity in Eastern Indonesia shed light on the 2018 Lombok and Palu earthquake sequences. Geophys. J. Int, 221: 1845-1855. https://doi.org/10.1093/gji/ggaa118

Susilo, S., A.B. Wijanarto, S. Wibowo, \& H Z. Abidin. 2018. GPS/GNSS analysis on Lombok earthquakes: Co-seismic deformation, Experimental Findings. https://doi.org/10.13140/RG.2.2.3487 1.78242

The Earthquake Hazard Program - USGS Website. [online]. https:// 
earthquake.usgs.gov/earthquake/. [diakses tanggal 20 Februari 2019].

Wang, C., X. Wang, W. Xiu, B. Zhang, G. Zhang, \& P. Liu. 2020. Characteristics of the seismogenic faults in the 2018 Lombok, Indonesia earthquake sequence as revealed by inversion of InSAR measurements. Seismological Research Letter, 91(4): 2152-2162. https://doi.org/10.1785/0220190002

Wang, X. 2009. User manual for COMCOT version 1.7 (First Draft).

http://ceeserver.cee.conell.edu.//phllgroup/comcot_down.htm

Wang, X. \& Philip. 2006. An analysis of 2004 Sumatra earthquake fault plane mechanisms and Indian Ocean tsunami. J. of Hydraulic Research, 44(2): 147-154. https:/doi.org/10.1080/00221686.200 6.9521671

Well's, L.D. \& J.K. Coppersmith. 1994. New empirical relationships among magnitude, rupture length, rupture width, rupture area and surface displacement. Bulletin of the Seismological Society of America, 84(4): 974-1002.

https://pubs.geoscienceworld.org/ssa/ bssa/articleabstract/84/4/974/119792/Newempirical-relationships-amongmagnitude?redirectedFrom=fulltext

Yudhicara, W. Kongko, V. Asvaliantina, Suranto, S. Nugroho, A. Ibrahim, S.W. Pranowo, B.N. Kerpen, F.K. Framer, \& O. Kunst. 2010. Jejak tsunami 25 Oktober 2010 di Kepulauan Mentawai berdasarkan penelitian kebumian dan wawancara. J. Lingkungan dan Bencana Geologi, 1(3): 165-181. https://doi.org/10.34126/jlbg.v1i3.19

Received : 03 February 2020

Reviewed: 05 May 2020

Accepted : 18 April 2021 